\title{
ZAKAT SEBAGAI DANA PEMBANGUNAN
}

\author{
Kiki Listari \\ STAIN Syaikh Abdurrahman Siddik Bangka Belitung
}

\begin{abstract}
This research is aim for the use of zakat as a development fund. The data is analyzed in descriptive qualitative point of view. Zakat is divided into two that is fitrah zakat and maal zakat. the use of zakat is only for 8 asnaf, their are fakir, poor, amil, mu'allaf, riqab, gharim, sabilillah, ibnu sabil. From these two kinds of zakat, none of zakat can be used as development fund. except for such development for the construction of places of worship, because the construction of a place of worship is one of the eight asnaf that is allowed to receive zakat. as described in QS.At-Taubah: 60. The construction of places of worship included into sabilillah category.
\end{abstract}

Keyword: zakat, fitrah, maal, development fund.

\section{A. Sumber Penerimaan Negara}

Pembangunan dalam negara adalah suatu keharusan yang harus dilaksanakan, baik itu pembangunan dibidang ekonomi, pendidikan maupun infrasruktur. Negara yang sedang berkembang menuju negara maju tidak bisa lepas dari kerja pemerintah dibidang pembangunan, tanpa di dukung oleh pembangunan yang berkontinyuitas maka perkembangan negara yang berkembang menuju negara maju sangatlah sulit. Masalah yang sering dialami negara yang sedang melakukan pembangunan di berbagai bidang adalah dana yang dibutuhkan tidak sebanding dengan anggaran dana yang dimiliki oleh pemerintah. Di indonesia sumber penerimaan negara terdiri dari pajak, bukan pajak dan hibah. Jika penerimaan negara tidak sebanding dengan pengeluaran 
yang dilakukan oleh pemerintah maka yang muncul adalah bertambahnya hutang negara kepada pihak luar.

Realisasi pendapatan negara semester I tahun 2017 mencapai Rp 719.249,3 miliar. Realisasi pendapatan negara tersebut terbagai atas pendapatan dari sektor pajak sebesar Rp 571.916,4 miliar, penerimaan bukan pajak (PNBP) sebesar Rp 146.119,8 miliar dan pendapatan dari hibah sebesar Rp 213,2 miliar. Sedangkan pada realisasi anggaran belanja negara pada semester I tahun 2017 mencapai $\operatorname{Rp} 893.318,6$ miliar. Realisasi belanja negara terdiri dari realisasi belanja pemerintah pusat sebesar Rp 498.560,5 miliar, transfer ke dana daerah dan desa sebesar Rp 394.758,2 miliar. $^{1}$

Berdasarkan data yang di sampaikan pemerintah Republik Indonesia dalam laporan pemerintah tentang pelaksanaan anggaran pendapatan dan belanja negara semester pertama tahun anggaran 2017, terlihat realisasi anggaran belanja negara lebih tinggi yaitu Rp 893.318,6 miliar dari realisasi pendapatan negara sebesar Rp 719.249,3 miliar. Hal ini menunjukkan bahwa terjadinya defisit anggaran dalam realisasi APBN semester I tahun 2017. Jika hal ini terus berlanjut maka kinerja pemerintah menjadi terganggu karena kekurangan dana yang dimiliki oleh pemerintah.

Untuk mengatasi defisit anggaran yang dialami pemerintah perlu dilakukan inovasi untuk peningkatan pendapatan negara. Selama ini pemerintah masih berfokus pada pendapatan negara dari sektor pajak, padahal masih ada sumber pendapatan negara dari sektor penerimaan bukan pajak yang jika dikelola dengan baik bisa menyaingi jumlah penerimaan negara dari sektor pajak. Adapun sumber penerimaan negara bukan pajak yang dimaksud adalah zakat.

${ }^{1}$ Laporan Tentang Pelaksanaan Anggaran Pendapatan dan Belanja Negara Semester I Tahun Anggaran 2017. https://www.kemenkeu.go.id/media/5475/lapsem-2017.pdf diakses tanggal 29 November 2017. Hal 3-2 
Indonesia sebagai negara dengan mayoritas penduduk muslim memiliki peluang penerimaan negara dari sektor zakat sangat tinggi. Selama ini zakat hanya dikelola oleh badan amil zakat (BAZNAS). Dana zakat yang diterima oleh BAZNAS dikelola dan dikembangkan oleh BAZNAS untuk kegiatan sosial. Bentuk kegiatan sosial yang sering dilakukan oleh BAZNAS diantaranya adalah pemberian beasiswa bagi siswa atau mahasiswa yang tidak mampu, pembangunan masjid, dan kegiatan sosial lainnya. Walaupun BAZNAS sering melakukan kegiatan sosial, BAZNAS tidak penah menyalurkan dana zakat kedalam bentuk pembangunan infrastruktur.

Pengelolaan zakat harus didasarkan pada aturan - aturan yang telah di tentukan oleh ajaran - ajaran dalam agama islam yang bersumberkan pada alqur'an, al hadist dan ijtima' para ulama. Dengan demikian jika pemerintah ingin memanfaatkan dana zakat, pemerintah harus mengikuti aturan - aturan yang ada dalam agama islam. Permasalahan yang sering muncul jika pemerintah ingin mengelola dana zakat sebagai dana pembangunan adalah penolakan dari masyarakat khususnya umat muslim karena persepsi masyarakat bahwa zakat tidak boleh digunakan sebagai dana pembangunan. Selain itu permasalahan yang juga perlu di perhatikan pemerintah adalah jenis zakat yang seperti apa yang boleh digunakan sebagai dana pembangunan, karena didalam ajaran islam ada beberapa jenis zakat yang harus dibayarkan oleh umat mulim kepada orang atau badan yang berhak menerimanya.

Berdasarkan permasalahan diatas penelitian ini membahas tentang bagaimana pandangan islam jika zakat dipergunakan sebagai dana pembangunan.

\section{B. Kajian Pustaka}

1. Tinjauan Zakat

a. Zakat 
Zakat menurut bahasa (lughat) berarti tumbuh, berkembang, kesuburan atau bertambah ( menurut hadist at-tarmidzi) atau dapat berarti membersihkan atau mensucikan, sebagaimana dijelaskan dalam Al-Qur'an surah At-Taubah ayat 103: "Ambilah zakat dari mereka, dengan zakat itu kamu membersihkan dan mensucikan mereka. Menurut hukum islam, zakat adalah nama bagi suatu pengambilan tertentu, menurut sifat tertentu dan untuk diberikan kepada golongan tertentu". Sedangkan menurut Undang - Undang no 38 tahun 1999 tentang pengelolaan zakat, zakat adalah harta yang wajib disisihkan oleh seorang muslim atau badan yang dimiliki oleh orang muslim sesuai ketentuan agama untuk diberikan kepada yang berhak menerimanya. ${ }^{2}$

Hafidhuddin (2002) menjelaskan bahwa zakat adalah salahsatu pilar penting dalam islam. Secara etismologis zakat memiliki arti kata berkembang, mensucikan dan berkah. Sedangkan secara terminologis zakat mempunyai arti mengeluarkan sebagian harta dengan persyaratan tertentu untuk diberikan kepada kelompok tertentu dengan persyaratan tertentu pula.

Zakat adalah salahsatu rukun islam, tiang agama yang menjadi dasar tegaknya agama dalam diri manusia. Dengan demikian maka upaya peningkatan secara mutlak terhadap keberadaan zakat dianggap kafir. Sebagai konsekuensinya orang yang tidak menunaikannya boleh diperangi dan diambil zakat hartanya secara paksa. Hal ini sebagaimana terjadi pada masa khalifah abu bakar dalam riwayat berikut :

Setelah rasulullah wafat, Abu Bakar diangkat menjadi khalifah dan sebagian orang arab menajdi kafir, lalu umar berkata " mengapa anda mau memerangi

${ }^{2}$ Direktorat Pemberdayaan Zakat . 2007. Standarisasi Manajemen Zakat. Departemen Agama 
orang/ padahal Rasulullah sudah bersabda " aku diperintahkan untuk memerangi manusia kecuali mereka mengucapkan " tiada Tuhan selain Allah". Maka siapapun yang mengucapkannya berarti darah, jiwa dan hartanya dijaga kecuali menurut haknya dan perhitungannya adalah atas Allah" lalu Abu Bakar menjawab "Demi Allah aku akan memerangi orang yang membedakan antara shalat dan zakat, karena zakat adalah hak harta. Demi Allah jika mereka enggan membayar infaq yang telah mereka bayarkan kepada Rasulullah, maka aku akan memeranginya karena keengganan tersebut" lalu Umar berkata "demi Allah itu berarti Allah telah melapangkan hati Abu Bakar, bahwa itulah yang benar ( HR. Bukhari) ${ }^{3}$

Dari hadist ini dapat diketahui bahwa zakat adalah suatu kewajiban yang harus ditunaikan oleh setiap muslim. Ancaman bagi orang orang yang secara sengaja menghindari pembayaran zakat sangatlah tegas. Hal ini juga Allah SWT tegaskan dalm Qs. Fushshilat : 7 yang artinya " orang - orang yang tidak menunaikan zakat dan mereka kafir terhadap akhirat".

b. Macam - Macam Zakat

Zakat adalah rukun islam ke 4, dengan demikian zakat bersifat wajib atas setiap muslim yang telah memenuhi syarat - syarat tertentu. Secara garis besar zakat terbagi atas 2 yaitu :

1) Zakat Nafs atau Zakat Fitrah

Zakat fitrah atau disebut juga zakat jiwa adalah zakat yang dikeluarkan pada bulan ramadhan dimana batas terakhir untuk pembayaran atau penyerahannya adalah ketikan imam naik ke mimbar untuk menyampaikann khutbah pada waktu pelaksanaan sholat idhul fitri. Adapun besarnya zakat fitrah menurut ukuran

\section{Hal 30}

${ }^{3}$ Direktorat Pemberdayaan Zakat. 2012. Membangun Peradaban Zakat. Departemen Agama RI. 
sekarag adalah 2,176Kg. Sedangkan makanan yang wajib dikeluarkan yang disebut nash hadist yaitu tepung, terigu, kurma, gandum, zabib dan aqith. Untuk daerah yang makanan pokoknya selain 5 diatas mahzab maliki dan syafi'i memperbolehkan membayar zakat dengan makan pokok lainnya. Menurut mahzab hanafi pembayaran zakat dapat dilakukan dengan membayar harganya dari makanan pokok yang dimakan.

2) Zakat Maal

Zakat maal adalah zakat yang dikeluarkan atas harta yang dimiliki atau dikuasai dan secara lazim dapat diambil manfaatnya. Secara syara harta dapat di definisikan sebagai segala sesuatu yang dikuasai dan dapat digunakan secara lazim. Antara lain mencakup hasil perniagaan, pertanian, pertambangan, hasil laut , hasil ternak, harta temuan, emas dan perak serta hasil kerja (profesi).

c. Landasan Hukum Kewajiban Zakat

Zakat adalah salahsatu dari rukun islam, hal ini menunjukkan bahwa zakat memiliki kedudukan sangat penting terkait ketaatan seorang muslim atas perintah Allah SWT. Zakat adalah suatu kewajiban setiap muslim yang harus dilaksanakan berdasarkan ketentuan - ketentuan dan syarat yang tertentu. Adapun kewajiban zakat ditegaskan oleh Allah SWT dalam Al-Qur'an surat al-baqoroh : 43 yang artinya " Dirikanlah shalat, tunaikan zakat, dan rukuklah bersama orang-orang yang rukuk". Kewajiban zakat ini ditegaskan juga dalam Al-Qur'an surah Al-Baqoroh :103 yang artinya "Ambilah zakat dari sebagian harta mereka, dengan zakat itu kamu membersihkan dan mensucikan mereka". 
Qardhawi (2007) menjelaskan teori tentang wajib zakat yaitu sebagai berikut :

1) Teori beban umum

Teori ini didasarkan bahwa merupakan hak Allah sebagai pemberi nikmat untuk membebankan kepada hambanya apa yang ia kehendaki baik kewajiban badani maupun harta, untuk melaksanakan kewajibannya dan tanda syukur atas nikmatnya.

2) Teori khalifah

Harta adalah amanah Allah. Dan manusia sebagai pemegang amanah atas harta itu. Harta kekayaan adalah rizki dari Allah untuk hamba sebagai anugerah dan nikmat darinya. Dan setelah memperoleh nikmat itu, ia harus mengeluarkan sebagian rizkinya itu denga tujuan meninggikan rahmat Allah dan menolong saudara -saudaranya sesama hamba Allah, sebagai tanda syukur atas segala nikmat yang diberikan kepadanya.

3) Teori pembelaan antara pribadi dan masyarakat Islam mewajibkan setiap orang yan gpunya kekayaan banyak untuk menunaikan hak - hak tertentu bagi kepentingan umum.

4) Teori persaudaraan

Masyarakat islam ibarat satu bangunan yang kokoh dan kuat, yang satu menunjang yang lainnya, saling tolong menolong dan saling menjaga satu sama lainnya.

d. Syarat - syarat zakat dan wajib zakat

Adapun syarat - syarat zakat adalah sebagai berikut :

1) Dimiliki dengan sempurna

2) Cukup nisab

3) Cukup haul

4) Lebih dari keperluan asas

5) Mencegah pengadaan didalam zakat. 
Sedangkan syarat - syarat wajib zakat :
1) Muslim
2) Aqil
3) Baligh
4) Milik Sempurna
5) Cukup Nisab
6) Cukup Haul.

2. Penelitian Terdahulu

Tabel 1. Penelitian Terdahulu

\begin{tabular}{|c|c|c|c|}
\hline No & Peneliti & Judul Penelitian & Hasil Penelitian \\
\hline 1 & Irfan Syauqi Beik & $\begin{array}{l}\text { Analisa Peran } \\
\text { Zakat dalam } \\
\text { Mengurangi } \\
\text { Kemiskinan : } \\
\text { Studi Kasus } \\
\text { Dompet Dhuafa } \\
\text { Republika }\end{array}$ & $\begin{array}{l}\text { Zakat mampu menguragi } \\
\text { jumlah dan presentase } \\
\text { keluarga miskin serta } \\
\text { mengurangi kedalaman } \\
\text { dan keparahan kemiskinan }\end{array}$ \\
\hline 2 & $\begin{array}{l}\text { Yogi Citra } \\
\text { Pratama }\end{array}$ & $\begin{array}{l}\text { Peran Zakat } \\
\text { Dalam } \\
\text { Penanggulangan } \\
\text { Kemiskinan ( } \\
\text { Studi Kasus : } \\
\text { Program Zakat } \\
\text { Produktif pada } \\
\text { Badan Amil } \\
\text { Zakat Nasional) }\end{array}$ & $\begin{array}{l}\text { Zakat yang dikembangkan } \\
\text { oleh mustahik dapat } \\
\text { digunakan sebagai modal } \\
\text { usaha dimana usaha yang } \\
\text { dikembangkan } \\
\text { mustahik pada umumnya } \\
\text { masih berskala kecil yang } \\
\text { tidak terakses oleh } \\
\text { lembaga keuangan bank. } \\
\text { Proses pendampingan }\end{array}$ \\
\hline
\end{tabular}




\begin{tabular}{|c|c|c|c|}
\hline & & & $\begin{array}{l}\text { mencakup perencanaan, } \\
\text { pelaksanaan, pengawasan } \\
\text { dan pengendalian serta } \\
\text { evaluasi program. Menjadi } \\
\text { salahsatu program amil } \\
\text { zakat dalam mengelola } \\
\text { zakat produktif sehingga } \\
\text { diharapkan menciptakan } \\
\text { sirkulasi ekonomi, } \\
\text { meningkatkan } \\
\text { produktifitas ekonomi } \\
\text { masyarakat, meningkatkan } \\
\text { pendapatan - pendapatan } \\
\text { secara ekonomi dan } \\
\text { berkelanjutan. }\end{array}$ \\
\hline 3 & $\begin{array}{l}\text { Abdul Kholiq } \\
\text { Syafa' at dan Lely } \\
\text { Anna Ferawati } \\
\text { Ekaningsih }\end{array}$ & $\begin{array}{l}\text { Potensi Zakat } \\
\text { Infaq Dan } \\
\text { Shodaqoh Pada } \\
\text { Badan Amil } \\
\text { Zakat Nasional } \\
\text { (BAZNAS) di } \\
\text { Kabupaten } \\
\text { Banyuwangi }\end{array}$ & $\begin{array}{l}\text { Berdasarkan hasil survei } \\
\text { potensi zakat pada tahun } \\
2103 \text { dari zakat gaji pokok } \\
\text { profesi PNS dari data BKD } \\
\text { sampai } 18 \text { November } 013 \\
\text { jumlah pegawai } \\
\text { pemerintah sebanyak } \\
\text { 13,058 orang, maka } \\
\text { proyeksi potensi dana } \\
\text { zakat yang akan di kelola } \\
\text { BAZNAS selama tahun } \\
2013 \text { Rp } 10.359 .735 .300 \text { per } \\
\text { tahun, maka ada peluang }\end{array}$ \\
\hline
\end{tabular}




\begin{tabular}{|c|c|c|c|}
\hline & & & $\begin{array}{l}\text { untuk meningkatkan } \\
\text { potensi jumlah muzaki } \\
\text { dan dana ZIS untuk tahun } \\
\text { yang akan datang }\end{array}$ \\
\hline 4 & I.M.Harafah & $\begin{array}{l}\text { Zakat sebagai } \\
\text { Alternatif } \\
\text { Pemberdayaan } \\
\text { Ekonomi Ummat }\end{array}$ & 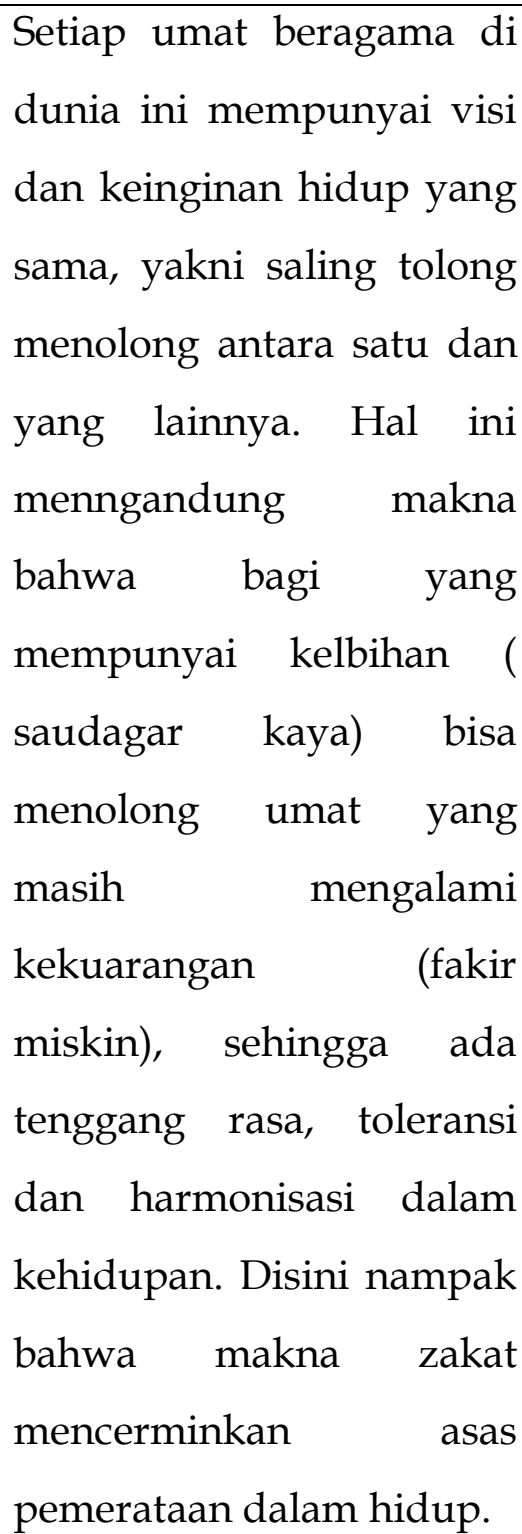 \\
\hline
\end{tabular}

\section{Desain dan Metode Penelitian}

1. Jenis dan Sumber Data

Sumber data dalam penelitian ini adalah data sekunder. Data sekunder adalah data yang diperoleh dari telaah literatur seperti buku, jurnal dan 
lain sebagainya. Penelitian ini tidak menggunakan data primer karena penelitian ini hanya menggunakan telaah literatur menggunakan buku dan jurnal.

2. Metode Penelitian

Metode analisa dalam peneltian ini menggunakan metode analisis deskriftif kualitatif.

\section{Pembahasan}

Pada bagian ini akan dipaparkan bagaimana pandangan islam jika dana zakat dipergunakan sebagai dana pembangunan. Banyak penelitian yang telah dilakukan terkait masalah zakat, terutama penelitian yang membahas tentang potensi zakat dalam mengentaskan kemiskinan. Walaupun demikian mengentaskan kemiskinan dan penggunaan dana zakat untuk pembanguan merupakan dua konsep yang berbeda. Jika zakat dipergunakan untuk mengentaskan kemiskinan maka potensinya sangat besar, karena dalam islam ada zakat fitrah yang dikeluarkan setahun sekali menggunakan makanan pokok. Besaran zakat yang harus dikeluarkan cukup banyak yaitu 2,176Kg/orang. Jika dikalikan dengan jumlah penduduk muslim di indonesia yang jumlah mencapai 207.176.162 (data sensus tahun 2010) ${ }^{4}$ maka jumlah penerimaan beras untuk zakat fitrah mencapai $450.815 .329 \mathrm{Kg}$. Jika dibagikan kepada masyarakat miskin (hasil sensus 2010) 31.020 .000 orang, maka tiap orang akan mendapatkan bagian zakat fitrah sebanyak 14,5Kg/ tahun. Jika dalam satu kepala keluarga terdapat 4 orang maka tiap kepala keluarga akan mendapatkan $58 \mathrm{Kg} /$ tahun. Angka ini belum termasuk dari penerimaan zakat lainnya. Dari data ini dapat disimpulkan bahwa zakat dapat berfungsi untuk megentaskan kemiskinan. Hal ini berbeda jika zakat digunakan sebagai dana

\footnotetext{
${ }^{4}$ https://sp2010.bps.go.id/index.php/site/tabel?tid=321 diakses tanggal 29 November 2017
} 
pembangunan. Walaupun zakat memiliki potensi sangat tinggi peningkatan penerimaan negara dari bukan pajak tetapi penggunaannya harus sesuai dengan aturan - aturan yang ada di dalam agama islam.

Pengumpulan zakat tidak dilakukan karena ada tidaknya kebutuhan negara dan kemaslahatan umat, seperti harta - harta lain yang dikumpulkan dari umat. Namun zakat merupakan jenis harta khusus yang wajib diserahkan atau dibayarkan oleh umat muslim baik itu ada kebutuhan dana atau tidak bagi umat. Zakat tidak gugur dari seorang muslim selama diwajibkan dalam hartanya. Ini artinya jika harta yang dimiliki oleh umat muslim sudah memenuhi syarat dan ketentuan zakat maka ia wajib untuk menyerahkan atau membayar zakat atas harta yang dimilikinya. Zakat harta ini lebih dikenal dengan istilah zakat maal.

Zakat maal adalah zakat yang dikeluarkan atas harta yang dimiliki atau dikuasai dan secara lazim dapat diambil manfaatnya. Walaupun zakat maal dapat diartikan sebagai zakat atas harta yang dimiliki bukan berarti semua harta yang dimiliki harus dibayarkan zakatnya karena dalam zakat maal ada syarat - syarat tertentu yang harus dipenuhi. Jika syarat tidak terpenuhi maka tidak ada kewajiban untuk membayar zakat atas harta yang dimiliki.

Dalam pengelolaannya zakat fitrah harus diserahkan kepada golongan yang berhak menerimananya pada hari raya atau paling lama ketika khotib sudah naik ke atas mimbar untuk menyampaikan khutbah sholat idul firi. Hal ini menunjukkan bahwa zakat fitrah tidak bisa dipergunakan untuk dana pembangunan karena ada batasan waktu penyerahan dan atau penyaluran zakat. Selain itu zakat fitrah umumnya berbetuk barang atau makanan pokok. Jika makanan pokoknya berupa gandum, maka zakat fitrah yang dibayarkan harus berbentuk gandum, atau contoh lainnya misalnya di indonesia makanan pokoknya menggunakan nasi ( beras) maka zakat fitrah yang harus dibayarkan oleh umat muslim adalah berbentuk beras. 
Pengelolaan dan penggunaan dana zakat harus sesuai dengan aturan yang disyaratkan dalam agama islam. Penggunaan dana zakat diterangkan dalam firman Alla SWT dalam Qs.At-Taubah :60 yang artinya:

"sesungguhnya zakat -zakat itu hanyalah untuk orang-orang fakir, orang orang miskin, para amil, dan para muallaf yang dibujuk hatinya, untuk memerdekakan budak dan orang-orang yang berutang, untuk jihad dijalan Allah dan orang - orang dalam perjalanan ".

Imam Jalalud-din Al-Mahalliy dalam tafsirnya menjelaskan ayat ini sebagai berikut :

"ayat ini menyatakan bahwa zakat tidak boleh diberikan kepada orang-orang selain mereka, dan tidak boleh pula mencegah zakat dari sebagian golongan diantara mereka bilamana golongan tersebut memang ada. Selanjutnya imamlah yang membagi -bagikannya kepada golongan - golongan tersebut secara merata; akan tetapi imam berhak mengutamakan individu-individu tertentu dari suatu golongan atas yang lainnya. Huruf Lam yang terdapat pada lafaz "Lilfuqoro" memberikan pengertian wajib meratakan pembagian zakat kepada setiap individu - individu yang berhak. Hanya saja tidak diwajibkan kepada pemilik harta yang dizakati, bilamana ia membaginya sendiri, mertakan pembagiannya kepada setiap golongan, karena hal ini ama sulit untuk dilaksanakan. Akan tetapi cukup baginya memberikannya kepada tiga orang dari setiap golongan. Tidak cukup baginya bilamana ternyata zakat hanya diberikan kepada kurang dari tiga orang" ${ }^{5}$

Dari tafsir yang disampaikan oleh Imam Jalalud-din Al-Mahalliy dapat ditarik kesimpulan bahwa, dana zakat hanya boleh disalurkan atau dipergunakan untuk delapan asnaf atau golongan. Hal ini diperkuat oleh tafsir yang disampaikan oleh Ibnu Katsir yang menyampaikan 8 golongan yang berhak menerima zakat yaitu fakir, miskin, amil, mu'allaf, riqab, gharim, sabilillah, ibnu sabil. 6

Berikut ini penjelasan lebih rinci tekait kedelapan asnaf yang berhak menerima zakat :

\footnotetext{
${ }^{5}$ Imam Jallalud-din Al-Mahalliy.1995. Tafsir Jalalain. Penerbit Sinarbaru Algesindo. Bandung. HIm 786-788.

${ }^{6}$ Bahreisy Salim, Said. 2005. Terjemah Singkat Tafsir Ibnu Katsir. PT Bina Ilmu. Surabaya. Hlm 75-82
} 
1. Fakir, yaitu orang yang tidak berharta dan tidak mempunyai pekerjaan atau usaha tetap, guna mencukupi kebutuhan hidupnya (nafkah), sedang orang yang menanggungnya (menjamin) tidak ada.

2. Miskin yaitu orang - orang tidak dapat mencukupi kebutuhan hidupnya, meskipun ia mempunyai pekerjaan atau usaha tetap, tetapi hasil usaha itu belum dapat mencukupi kebutuhannya dan orang yang menanggung ( menjamin) tidak ada.

3. Amil, yaitu orang atau panitia / organisasi yang mengurusi zakat baik mengumpulkan, membagi atau mengelola.

4. Mu'allaf, yaitu orang yang masih lemah imannya karena baru masuk islam tetapi masih lemah ( ragu - ragu ) imannya itu.

5. Riqab ( hamba sahaya) yang mempunyai perjanjian akan di merdekakan oleh majikannya degan jalan menebus dengan uang.

6. Gharim yaitu orang yang mempunyai hutang karena suatu kepentingan yang bukan maksiat dan tidak mampu melunasinya.

7. Sabilillah yaitu usaha - usaha yang tujuannya untuk meninggikan syiar agama islam seperti membela/ mempertahankan agama, mendirikan tempat ibadah, pendidikan dan lembaga-lemabaga keagamaan lainnya.

8. Ibnu sabil yaitu orang yang kehabisan bekal dalam bepergian dengan maksud baik.

Zakat terbagi atas dua macam yaitu zakat fitrah dan zakat maal. Zakat fitrah adalah zakat yang dikeluarkan pada bulan ramadhan dimana batas akhir pembayaran atau penyerahan zakatnya adalah ketika khotib naik ke atas mimbar untuk menyampaikan khutbah sholat idul fitri. Pembayaran atau penyerahan zakat fitrah yang dilakukan umat muslim hanya boleh menggunakan makanan pokok yang sering di konsumsi sehari - hari oleh umat muslim di daerah masing - masing. Walaupun ada perbedaan tentang alat penyerahan zakat fitrah dimana ada pendapat yang 
memperbolehkan pembayaran zakat fitrah menggunakan uang tunai senilai makanan pokok yang disyaratkan tetapi dalam pelaksanaan penyaluran zakat tersebut tidak ada perbedaan waktu dan golongan yang berhak menerima. Sedangkan zakat maal waktu pembayaran dan penyaluran diserahkan sepenuh nya kepada badan yang bertanggung jawab untuk mengurusi zakat. Artinya tidak ada batasan waktu penyaluran untuk zakat maal.

Dalam tafsir QS. At-Taubah yang disampaikan oleh Imam Jalaluddin Al-Mahalliy dan Ibnu Katsir dapat diketahui bahwa pengelolaan dan penyaluran zakat hanya boleh di pergunakan kepada delapan golongan. Selain delapan golongan tersebut dana zakat tidak boleh dipergunakan. Dengan demikian walaupun potensi penerimaan negara dari zakat sangat tinggi pengelolaan dan penggunannya tidak boleh digunakan sebagai dana pembangunan secara umum seperti pembangunan jalan, pembangunan kantor - kantor pemerintah dan pembangunan - pembangunan lainnya. Dana zakat dapat dipergunakan sebagai dana pembangunan untuk pembangunan - pembangunan tertentu seperti pembangunan masjid atau tempat ibadah lainnya. Pengkategorian pembangunan untuk fasilitas tempat ibadah seperti masjid diperbolehkan karena ia termasuk kedalam salahsatu delapan asnaf yang diperbolehkan untuk menerima penyaluran zakat yaitu termasuk kategori sabilillah.

\section{E. Kesimpulan dan Saran}

Zakat adalah salahsatu unsur penerimaan negara dari bukan pajak, zakat hanya boleh dikenakan atau diwajibkan kepada umat muslim saja. Dalam pengelolalaannya zakat dapat di kategorikan kedalam dua macam, yaitu zakat fitrah dan zakat maal. Zakat fitrah adalah zakat yang dikeluarkan pada bulan ramadhan dimana batas terakhir untuk pembayaran atau penyerahannya adalah ketikan imam naik ke mimbar untuk menyampaikann khutbah pada 
Kiki Listari

waktu pelaksanaan sholat idhul fitri. Pembayaran zakat fitrah pun hanya boleh menggunakan makanan pokok yang sering dikonsumsi oleh umat muslim. Misalnya umat muslim yang makanan pokok sehari - harinya roti maka zakat fitrah yang dibayarkan adalah roti, tetapi jika makanan pokoknya adalah nasi (beras) maka zakat fitrah yang dibayarkan mengunakan beras. Karena peerimaan zakat fitrah ini berbentuk barang ( makanan pokok) maka sangat jelas sekali jenis zakat ini tidak bisa dipergunakan untuk dana pembangunan. Sedangkan untuk zakat maal, menurut QS. At -Taubah : 60 dapat ditarik kesimpulan bahwa yang berhak menerima zakat hanyalah delapan asnaf yaitu fakir, miskin, amil, mu'allaf, riqab, gharim, sabilillah, ibnu sabil. Dengan demikian jenis zakat ini juga tidak boleh dipergunakan untuk dana pembangunan. Walaupun demikian ada jenis pembangunan yang diperbolehkan menggunakan dana zakat yaitu pembangunan tempat ibadah, hal ini dikarenakan pemabangunan tempa ibadah masuk kedalam salahsatu asnaf yang berhak menerima zakat yaitu kategori sabilillah. 


\section{DAFTAR PUSTAKA}

Bahreisy Salim, Said. 2005. Terjemah Singkat Tafsir Ibnu Katsir. PT Bina Ilmu. Surabaya

Beik Irfan Syauqi. 2009. Analisa Peran Zakat dalam Mengurangi Kemiskinan : Studi Kasus Dompet Dhuafa Republika. Jurnal Pemikiran dan Gagasan. Vol 2

Direktorat Pemberdayaan Zakat . 2007. Standarisasi Manajemen Zakat. Departemen Agama RI

Direktorat Pemberdayaan Zakat. 2012. Membangun Peradaban Zakat. Departemen Agama RI

Hafidhuddin, D.2002. Zakat dalam Perekonomian Modern. Gema Insani Press. Jakarta.

Harafah I.M. 2010. Zakat Sebagai alternatif Pemberdayaan Ekonomi Umat. Jurnal Al A'dl. Vol 3 No 2

https://sp2010.bps.go.id/index.php/site/tabel?tid=321 diakses tanggal 29 November 2017

Imam Jallalud-din Al-Mahalliy.1995. Tafsir Jalalain. Penerbit Sinarbaru Algesindo. Bandung.

Laporan Tentang Pelaksanaan Anggaran Pendapatan dan Belanja Negara $\begin{array}{lllll}\text { Semester I } & \text { Tahun Anggaran }\end{array}$ https://www.kemenkeu.go.id/media/5475/lapsem-2017.pdf diakses tanggal 29 November 2017

Pratama Yogi Citra. 2015. Peran Zakat Dalam Penanggulangan Kemiskinan ( Studi Kasus : Program Zakat Produktif pada Badan Amil Zakat Nasional). The Journal of Tauhidinomics. Vol 1 no 1

Qardawi Yusuf. 2007. Hukum Zakat. Bogor. Litera Antar Nusa.

Syafa'at Abdul Kholiq, Lely Anna Ferawati Ekaningsih. 2015. Potensi Zakat Infaq Dan Shodaqoh Pada Badan Amil Zakat Nasional (BAZNAS) di Kabupaten Banyuwangi. Jurnal Penelitian Sosial Keagamaan. Vol 9 No 1. 